KS. KAZIMIERz ŚwIĘS

\title{
Centesimus annus - pastoralny wgląd w rok 1989
}

Według zamysłu św. Jana Pawła II celem encykliki Centesimus annus było „spojrzenie w przeszłość, ale przede wszystkim skierowanie uwagi ku przyszłości. Podobnie jak encyklika Rerum novarum, stoi ona niejako na progu nowego wieku i pragnie z Bożą pomocą przygotować jego

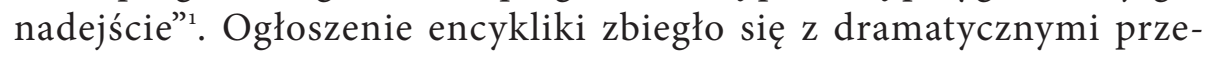
obrażeniami politycznymi, gospodarczymi, kulturowymi, jakie miały miejsce w roku 1989, a których nawet krótko przedtem nikt nie mógł sobie wyobrazić ani przewidzieć. Rok ten jest expressis verbis wiele razy wymieniany w tekście dokumentu, a cały trzeci rozdział encykliki nosi tytuł „Rok 1989”. Ojciec święty przeprowadził analizę społecznej, politycznej i gospodarczej sytuacji, która powstała po upadku socjalizmu i totalitarnych systemów przemocy w Europie Środkowej i Wschodniej. Zachęcał przy tym do rozważenia okoliczności, w jakich ogłoszona była słynna Leonowa encyklika Rerum novarum, a także do przemyślenia zmian, jakie zaszły w ciągu ostatniego stulecia. Refleksja ta ma także ożywiać myślenie o przyszłości. Do tej metodycznej propozycji nawiązują poniższe rozważania, w których z perspektywy 25 lat od ogłoszenia encykliki Centesimus annus podjęto próbę wydobycia pastoralnych

\section{CA 62.}

CA 22-29.

Ważniejsze oznaki zmian w roku 1989 to: w Polsce rozmowy rządu ze zdelegalizowaną "Solidarnością" i zwycięstwo antykomunistycznej opozycji w wyborach 4 czerwca; na Węgrzech otwarcie granic z Zachodem i rehabilitacja Imre Nayga; w Niemczech Wschodnich ustąpienie Ericha Honeckera i obalenie muru berlińskiego 9 listopada; aksamitna rewolucja w Czechosłowacji i wybór pisarza Václava Havla na prezydenta; w Rumunii 25 grudnia stracenie małżeństwa Ceauşescu - pary dyktatorów. Znaczącym wydarzeniem była też rozmowa Gorbaczowa z Janem Pawłem II w Watykanie 1 grudnia. 
aspektów refleksji nad wydarzeniami roku 1989. Przegląd komentarzy i opracowań, jakie sukcesywnie pojawiały się po wydaniu encykliki, dowodzi, że w przeważającej mierze poruszają one kwestie socjalne, ekonomiczne, polityczne, kulturowe. O wiele mniej jest rozważań o charakterze teologicznym. Tymczasem, jak niektórzy sądzą, encyklika nie jest dokumentem ekonomicznym, ale pastoralnym. Jej pastoralny charakter oznacza, że Kościół w tym dokumencie dokonuje moralnej oceny systemu produkcji i konsumpcji, osądza $z$ etycznego punktu widzenia jego wpływ na życie ludzi, których mocno uzależnia, nawet jeśli nie narusza wprost ich wolności ${ }^{4}$. Pastoralny wgląd encykliki w społeczne i polityczne przemiany nie może uchylać się od wartościowania zjawisk społecznych, w przeciwieństwie do analiz czysto socjologicznych, które pozostają w obszarze rzeczywistości dostępnej jedynie badaniom empirycznym.

\section{Pastoralny charakter dokumentu}

Aby uchwycić i zrozumieć teologiczne aspekty encykliki Centesimus annus, konieczne wydaje się przypomnienie ewolucji, jaka dokonała się w nauce społecznej Kościoła, począwszy od Leona XIII, który dał impuls do systematycznego opracowywania tej nauki. Początkowo przeważała wizja „solidaryzmu”. Ta koncepcja porządku społecznego wydawała się swojego rodzaju chrześcijańską drogą pomiędzy socjalizmem a liberalizmem. Do tej wizji wyraźnie nawiązywała myśl Piusa XI w encyklice Quadragesimo anno, w której znalazła się realna alternatywna propozycja dla indywidualnego liberalizmu i socjalistycznego kolektywizmu. Odwołanie się do zasad moralnych i antropologicznych w porządkowaniu życia społecznego dyktowane było z pewnością światowym kryzysem ekonomicznym, upadkiem instytucji finansowych, masowym ubóstwem. Katolicka nauka społeczna w dużym stopniu bazowała na prawie naturalnym i naukach społecznych. Oparta na nich wizja ładu społeczno-ekonomicznego wydawała się bardziej skuteczna w walce z przejawami niesprawiedliwości i krzywdy społecznej. Mniej uwagi przywiązywano do kwestii i rozważań teologicznych. Taka koncepcja doktryny społecznej Kościoła miała z jednej strony swe zasługi w promowaniu strukturalnych

\footnotetext{
4 S. B. Restrepo, Odczytujac "Centesimus annus” w nowym tysiącleciu, „Społeczeństwo” 43-44 (2001), nr 3-4, s. 401.
} 
rozwiązań w imię sprawiedliwości, akceptowaniu kapitalistycznej formy gospodarki z zaleceniem jej korekty, chociażby przez państwowy interwencjonizm. $Z$ drugiej jednak strony ujęcie to niosło ze sobą niezrozumienie dla funkcjonowania instytucji państwa o ustroju liberalnym, demokracji, znaczenia rynkus.

Zwiastunami zmiany kierunku był: roztropna akceptacja demokracji przez Piusa XıI, nauczanie Jana xxıII o prawach człowieka, aż po pełny wykład Gaudium et spes na temat sytuacji Kościoła w świecie współczesnym. Zasadniczego przełomu w rozumieniu nauki społecznej Kościoła dokonał Ojciec święty Jan Paweł II. Odrzucił on ideę pojmowania tej nauki jako „trzeciej drogi” pomiędzy liberalnym kapitalizmem i marksistowskim kolektywizmem; uznał ją natomiast za „kategorię niezależną", o wyraźnie teologicznym charakterze. Według Jana Pawła II nauka społeczna Kościoła jest „dokładnym sformułowaniem wyników pogłębionej refleksji nad złożoną rzeczywistością ludzkiej egzystencji w społeczeństwie i w kontekście międzynarodowym, przeprowadzonej

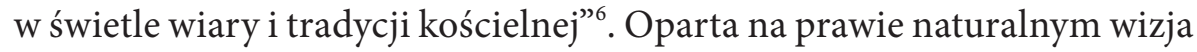
budowania ładu społecznego została zastąpiona chrześcijańską refleksją nad życiem społecznym i politycznym. Konsekwencje tej zmiany widać w encyklice Centesimus annus, gdzie znajduje się wyraźne nawiązanie do refleksji z zakresu teologii. Zdaniem jej autora „zarówno interpretacja, jak i rozwiązanie aktualnych problemów ludzkiego współżycia wymaga uwzględnienia ich wymiaru teologicznego"'. W tym też duchu należy odczytać wskazanie, że nauka o grzechu pierworodnym ,jest nie tylko integralną częścią chrześcijańskiego Objawienia, ale ma również wartość hermeneutyczną, gdyż pozwala zrozumieć ludzką rzeczywistość”. Ten teologiczny zwrot - jak podkreśla jeden z komentatorów papieskiego nauczania - „paradoksalnie otwiera drogę do głębszego zrozumienia i zasadniczej akceptacji rzeczywistości instytucjonalnej nowoczesnego państwa konstytucyjnego, demokracji i zasad rynkowych, nie pomijając

5 M. Rhonheimer, Polityczny i ekonomiczny realizm współczesnego świata oraz jego założenia etyczne i kulturowe. Encyklika "Centesimus annus” - 1 maja 1991 roku, w: Jan Paweł II Teolog. Komentarze do encyklik, red. G. Borgonovo, A. Cattaneo, wstęp do wyd. pol. K. Nycz, tłum. E. Augustyn, R. Cielicki, Warszawa 2009, s. 151-153.

6 SRS 41.

7 CA 55.

8 CA 25. 
przy tym obaw i tradycyjnych zasad wynikających z nauki społecznej Kościoła" .

Tytuł obecnego paragrafu może wydawać się dyskusyjny. Chodzi jednak tylko o wskazanie pewnego zespołu cech encykliki, które świadczą o teologicznym spojrzeniu Jana Pawła II na wydarzenia roku 1989. Wskazanie na pastoralnoteologiczne wątki encykliki Centesimus annus wymaga krótkiego komentarza na temat specyfiki samej teologii pastoralnej oraz jej metody. Kwestie te pozostają wciąż w polu dyskusji pomiędzy teologami. Duża zgodność panuje jednak w akceptacji tezy, iż chodzi tutaj o refleksję nad aktualną sytuacją Kościoła w społeczeństwie, w teraźniejszości. Proponowane jest zatem uwzględnienie kontekstu społecznego i aspektu socjologicznego ${ }^{10}$. Warto także przypomnieć słowa samego Ojca świętego Jana Pawła II, który w adhortacji Pastores dabo vobis napisał, że „teologia pastoralna nie jest tylko umiejętnością, zespołem wskazań, doświadczeń i metod. Ma status pełnoprawnej dyscypliny teologicznej, ponieważ czerpie z wiary zasady i kryteria działalności duszpasterskiej Kościoła w historii [...]. Wśród tych zasad i kryteriów szczególnie ważne miejsce zajmuje ewangeliczne rozeznanie sytuacji społeczno-kulturalnej i kościelnej, w której prowadzona jest działalność duszpasterska" ${ }^{11}$. Na to właśnie „ewangeliczne rozpoznanie sytuacji społeczno-kulturalnej i kościelnej” obecne w encyklice Centesimus annus skierowana jest uwaga niniejszego artykułu. Konkretna bowiem sytuacja, w której przypada Kościołowi spełniać swoje posłannictwo, nie jest przypadkiem, ale przewidzianym przez Boga czasem. W takim ujęciu sytuacja ta jest elementem konstytutywnym zbawczej działalności, a jej badanie staje się analizą teologiczną, chociaż opartą na przesłankach dostarczonych przez nauki empiryczne, opisujące rzeczywistość społeczną ${ }^{12}$.

Co do samej metody, to w teologii pastoralnej występują różne paradygmaty postępowania badawczego. Jednym $z$ dawniejszych, ale powszechnie przyjmowanym, jest paradygmat kard. Josefa Cardijna (widzieć - ocenić - działać). Zalecany był on przez Jana xxıII w encyklice

\footnotetext{
9 M. Rhonheimer, Polityczny i ekonomiczny realizm współczesnego świata..., s. 156-157.

10 R. Kamiński, Tożsamość metodologiczna teologii pastoralnej, w: Metodologia teologii praktycznej, red. W. Przyczyna, Kraków 2011, s. 37-38.

${ }^{11}$ Jan Paweł II, Posynodalna adhortacja apostolska Pastores dabo vobis, 57.

${ }^{12}$ R. Kamiński, Tożsamość metodologiczna teologii pastoralnej, s. 44.
} 
Mater et magistra jako metoda wprowadzania w życie zasad społecznego nauczania Kościoła ${ }^{13}$. Drugi to paradygmat trzech etapów analizy pastoralnoteologicznej, stworzony przez przedstawicieli nurtu eklezjologicznego w teologii pastoralnej. Są to następujące etapy: kryteriologiczny (eklezjologiczny), kariologiczny (socjologiczny), prakseologiczny (strategiczny). Trzeci paradygmat to analiza prakseologiczna działalności zbawczej Kościoła ${ }^{14}$.

Wydaje się, że pastoralny osąd papieża nad rokiem 1989 oparty jest, w dużej mierze, na pierwszym $\mathrm{z}$ wymienionych wyżej paradygmatów analizy pastoralnej. Punktem wyjścia rozważań jest bowiem opis przemian, analiza ich przyczyn, przebiegu oraz konsekwencji. Sprawą drugorzędną jest formalne zakwalifikowanie tego opisu do obszaru teologii pastoralnej czy też katolickiej nauki społecznej. Obydwie bowiem dyscypliny w swej teoretycznej refleksji spotykają się na płaszczyźnie rozeznania rzeczywistości społecznej. Obydwie korzystają z wyników nauk empirycznych opisujących tę rzeczywistość. Jednak etap badawczy określony pojęciem „widzieć” tak w teologii pastoralnej, jak i w nauce społecznej Kościoła nie wyczerpuje się w opisie rzeczywistości społecznej. On już zawiera elementy teologiczne, ściśle związane $\mathrm{z}$ oceną tej rzeczywistości ${ }^{15}$.

Ksiądz Wiesław Przygoda, powołując się na niemieckiego pastoralistę Josefa Müllera, zauważa, że na etapie stawiania diagnozy teologia pastoralna nie może ograniczyć swego krytycznego postrzegania tylko do zewnętrznej strony rzeczywistości, ale musi uwzględniać jej duchowy wymiar, a to zobowiązuje do otwartej postawy wobec wyzwań, jakie wypływają z diagnozowania sytuacji zbawczej ${ }^{16}$. Specyfika spojrzenia pastoralnego na konkretne sytuacje społeczne przejawia się także w tym, że teolog pastoralny, nawet na etapie opisu rzeczywistości, nie może zadowolić się analizą sytuacji współczesnego świata, prowadzoną przez socjologię, psychologię, ekonomię i inne nauki świeckie. Musi mieć świadomość, że każda sytuacja ma także aspekt teologiczny, gdyż jest odezwaniem się Boga do Kościoła. Element teologiczny w analizie

\footnotetext{
13 MM 236.

${ }^{14}$ W. Przygoda, Paradygmaty postępowania badawczego w teologii praktycznej, w: Metodologia teologii praktycznej, s. 98-107.

${ }_{15}$ S. Fontana, Corpus doktrynalny. Nauka społeczna jako organiczna całość, „Społeczeństwo" 9 (1999), nr 1, s. 68.

${ }^{16}$ W. Przygoda, Paradygmaty postępowania badawczego w teologii praktycznej, s. 99.
} 
zjawisk społecznych polega na swoistej interpretacji wyników tej analizy w świetle istoty Kościoła i zamierzonych planów Bożych wobec Kościoła $^{17}$. To spostrzeżenie jest znaczące dla zrozumienia i interpretacji obecnej w Centesimus annus analizy przemian społecznych roku 1989. Kongregacja ds. Wychowania Katolickiego, wypowiadając się na temat metod rozeznania w nauce społecznej Kościoła, stwierdza, że pozwala ono „nie tylko lepiej zrozumieć sytuacje lokalne, regionalne czy o zasięgu światowym, ale także - i przede wszystkim - odkrywać zbawczy plan Boga zrealizowany w Jezusie Chrystusie, a dotyczący wszystkich jego dzieci w różnych epokach historycznych"18. To stwierdzenie naprowadza na myśl o fundamentalnie pastoralnym charakterze nauczania społecznego Kościoła.

Pastoralny wgląd encykliki w przemiany społeczne roku 1989 przejawia się w tym, że dają się w nim odnaleźć wskazane wyżej elementy pastoralnej analizy, według schematu: widzieć - ocenić - działać. W encyklice Centesimus annus znajdujemy zwięźle zarysowaną sytuację dzisiejszego świata oraz przypomniane istotne zmiany, jakie dokonały się w perspektywie minionego wieku. Refleksja ta ułatwia zrozumienie samych wydarzeń roku 1989 i pierwszych miesięcy roku 1990 oraz ich dalszych konsekwencji ${ }^{19}$. Te ostatnie dotyczą głównie krajów Europy Środkowej i Wschodniej oraz są traktowane jako kulminacyjny punkt przemian. Ojciec święty osądził upadek systemu socjalistycznego oraz wskazał drogę prowadzącą do odrodzenia i rozwoju społeczeństw ludzkich w przyszłości. Nie wolno jednak przesłania encykliki zacieśniać do określonych ram geograficznych ani do samego historycznego faktu obalenia komunizmu. Skutki upadku realnego socjalizmu dały się odczuć nie tylko w bloku państw socjalistycznych w Europie oraz krajach Azji, Afryki czy Ameryki Południowej, pozostających w orbicie wpływów Związku Sowieckiego. Konsekwencje tych przemian odczuły także państwa będące pod wpływem ideologii socjalizmu. Wystarczy wspomnieć centralnie sterowane gospodarki oparte na dominacji państwowej własności środków pro-

${ }_{17}$ R. Kamiński, Tożsamość metodologiczna teologii pastoralnej, s. 53.

${ }^{18}$ Kongregacja ds. Wychowania Katolickiego, Wskazania dotyczące studiów i nauczania doktryny społecznej Kościoła w ramach formacji kapłańskiej, nr 8, „L'Osservatore Romano”, wyd. pol., 10 (1989) $\mathrm{nr}$ 7, s. 11.

${ }_{19}$ Por. CA 12. 
dukcji oraz łagodniejsze formy zwierzchności państwa, dopuszczającego pewne przejawy prywatnej inicjatywy. Model socjalistyczny był też atrakcyjny dla wielu krajów Trzeciego Świata, które widziały w nim sposób na sprawiedliwy rozwój po erze kolonialnej. Wpływy socjalizmu dały się także zauważyć w wysoko rozwiniętych państwach kapitalistycznych Zachodu. Chodzi tutaj o manifestowanie przez różne grupy społeczne idei socjalistycznych czy socjaldemokratycznych oraz wymuszanie przez opiniotwórcze elity zmian i rozwiązań zmierzających do poszerzenia wpływu państwa na gospodarkę i życie obywateli ${ }^{20}$.

Rozpad komunizmu i przemiany we wszystkich obszarach życia nie dokonały się od razu, natychmiast. Poprzedzały je inne wydarzenia, jak masowe protesty, powstania i strajki. Niektóre z nich się nie powiodły, jak w przypadku powstania węgierskiego z 1956 roku; inne zakończyły się powodzeniem, jak ruch „Solidarność” w Polsce. W te trudne dzieje wpisują się wysiłki pojedynczych osób i małych grup, świadectwa ich wiary we własne możliwości i wymuszonej wolności sumienia oraz wywalczonych praw człowieka i obywatela, jak również dokonań społecznej samoorganizacji $z$ dala od struktur władzy państwa partyjnego ${ }^{21}$. Trudno zaprzeczyć, że motorem tych działań była narastająca świadomość praw człowieka, do której walnie przyczyniła się działalność Kościoła, o czym Jan Paweł II wspomina w encyklice ${ }^{22}$.

Na płaszczyźnie oceny znajdujemy w encyklice wiodące perspektywy. Najpierw teologiczną, czyli powiązanie z treścią orędzia zbawczego, dalej uniwersalną w sensie treści i adresatów (wszyscy ludzie dobrej woli) oraz historyczną w znaczeniu dziejowej aktualności troski społecznej Kościoła. W perspektywie historycznej należy odróżnić wymienione w encyklice „rzeczy nowe”, do których trzeba się odnieść, od tego, co jest nowością w sensie interpretacji wydarzeń dziejowych. W pierwszym znaczeniu nowością jest sytuacja kapitalizmu we współczesnym świecie. Sam upadek socjalizmu jest tylko punktem wyjścia i nie może przesłaniać centralnego problemu, jakim jest kapitalizm bez systemowej konkurencji. Nowością

\footnotetext{
${ }^{20}$ J. Michałowski, „Centesimus annus” - jaki kapitalizm, w: Jan Paweł II, „Centesimus annus”. Tekst i komentarze, red. F. Kampka, C. Ritter, Lublin 1998, s. 227-228.

${ }^{21}$ B. Oschovsky, Rok 1989 - europejski czas pamięci, http://www.enrs.eu/pl/articles/ 130-rok-1989-europejski-czas-pamieci (14.01.2016).

${ }^{22}$ Zob. CA 22.
} 
w sensie merytorycznym, czyli nowością interpretacji wydarzeń zachodzących w ciągu dziejów, jest pozytywna ocena rynku i poszerzenie rozumienia własności ${ }^{23}$. Należy jednak zaznaczyć, że w encyklice nie ma naiwnej pochwały dla rynku i liberalnej demokracji, chociaż w świecie panował wówczas entuzjazm po upadku komunizmu. Być może ten entuzjazm był powodem mocno zideologizowanych stanowisk wielu komentatorów encykliki, którzy byli przekonani o absolutnej dominacji neoliberalizmu. Nawet wbrew stanowisku samego jej autora. Tu trzeba też przywołać inne jednostronne odczytywanie encykliki przez tych, którzy widzieli w niej zdradę sprawy ubogich i kompromis Kościoła z kapitalizmem ${ }^{24}$.

Propozycje działania uzależnione są od skutków wywołanych wydarzeniami z 1989 roku. Pozytywnym ich następstwem było zbliżenie pomiędzy Kościołem a ruchem robotniczym, wyzwolenie woli dialogu i ducha ewangelicznego w zmaganiach o sprawiedliwy ład społeczny. Równocześnie jednak pojawiła się obawa, iż spuścizną systemu socjalistycznego mogą być tendencje szowinistyczne, konflikty międzynarodowe. Wobec tych zagrożeń konieczne jest budowanie międzynarodowej solidarności, pomocy dla byłych krajów komunistycznych oraz krajów Trzeciego Świata, redukcja zbrojeń i przeciwdziałanie handlowi bronią, tworzenie lub umacnianie międzynarodowych struktur, które mogą interweniować w razie konfliktu ${ }^{25}$. Integralna koncepcja rozwoju domaga się także działań na rzecz godności każdej osoby, tak by mogła realizować swe powołanie, w którym zawiera się wezwanie Boże. Kończąc refleksję nad wydarzeniami roku 1989, Jan Paweł II z naciskiem domaga się uznania w całości praw ludzkiego sumienia, związanego tylko z prawdą, czy to naturalną, czy też objawioną. Uznanie tych praw jest pierwszą zasadą wszelkiego porządku politycznego prawdziwie wolnego ${ }^{26}$. Papieskie argumenty za potwierdzeniem tej zasady są niepodważalne: niebezpieczeństwo odradzania się totalitaryzmów i autorytaryzmów, przesadna propaganda wartości czysto utylitarnych w krajach rozwiniętych, która

\footnotetext{
${ }^{23}$ T. Żeleźnik, Encyklika „Centesimus annus” i przemiany w Polsce, „Społeczeństwo” 4344 (2001), nr 3-4, s. 407.

${ }^{24}$ S. B. Restrepo, Odczytujac „Centesimus annus” w nowym tysiącleciu, s. 399.

${ }_{25}$ Por. CA 27, 28.

${ }^{26}$ CA 29.
} 
utrudnia uznanie i szacunek dla prawdziwych wartości ludzkiej egzystencji, nowe formy fundamentalizmu religijnego ${ }^{27}$. Z perspektywy 25 lat, jakie upłynęły od ogłoszenia encykliki Centesimus annus, okazuje się, jak dalekowzroczna i prorocza była refleksja Jana Pawła II nad „nowymi rzeczami” naszych czasów. W dokumencie ze szczególną wnikliwością przewidziano zjawiska społeczne, które dziś występują tak w starych, jak i w młodych demokracjach. Zdaniem George’a Weigla „stało się tak dlatego, że Ojciec święty nadał swym analizom życia społecznego w zasadniczym stopniu charakter nie polityczny czy ekonomiczny, ale raczej teologiczny i filozoficzny" ${ }^{28}$.

\section{2. „Znaki czasu” w wydarzeniach roku 1989}

Treść całej encykliki, a szczególnie refleksję nad rokiem 1989, trzeba ujmować w perspektywie całości nauczania św. Jana Pawła II. Mają rację ci autorzy, którzy widzą w papieskiej myśli wielki dialog ze światem współczesnym. Krótką charakterystykę tego świata dał Ojciec święty już w dniu inauguracji swego pontyfikatu, gdy wołał: „Otwórzcie drzwi Chrystusowi”. Wezwanie to stawia przed oczy specyficzny obraz świata, jakby za zamkniętymi drzwiami, i obraz Boga stojącego jakby na zewnątrz świata. Świat jest zamknięty w kręgu własnej historii, jest światem żyjącym własnym czasem. Obok niego toczy się osobnym torem historia zbawienia $^{29}$. Jan Paweł II w swoim posługiwaniu na Stolicy Piotrowej podjął konsekwentny wysiłek zjednoczenia historii własnej każdego człowieka $\mathrm{z}$ historią zbawienia. Wszystkie wydarzenia historii są odnoszone do Chrystusa i oceniane w świetle Jego Osoby. W taki sposób czas staje się warunkiem zbawienia dla ludzkości i dla wszechświata. Historia świata staje się święta ${ }^{30}$. „Historia zbawienia - pisze Ojciec święty - podejmuje nie tyle problem samych dziejów człowieka, ile problem sensu jego bytowania. Jest ona więc historią i zarazem metafizyką. Jest w pewnym sensie najbardziej integralną teologią - teologią wszystkich spotkań pomiędzy

27 Tamże.

${ }^{28}$ G. Weigel, „Centesimus annus” a przyszłość demokracji: powtórna lektura, w: Jan Paweł II, „Centesimus annus”. Tekst i komentarze, s. 116.

${ }^{29}$ P. Bortkiewicz, Nauczyciel myślenia. Wokót myśli Jana Pawła II, Gdańsk 2005, s. 9.

${ }^{30}$ K. Ryczan, Chrystolog dziejów, w: Świadka świadkowie, red. M. Rusecki, S. Wilk, Lublin 2008 , s. 28. 
Bogiem i światem"31. Kluczowe dla zrozumienia papieskiej diagnozy wydarzeń roku 1989 jest też spojrzenie na sens dziejów w interpretacji Jana Pawła II. Papież postrzega człowieka i historię przez pryzmat Jezusa Chrystusa. W Chrystusie jako Synu Bożym, który stał się człowiekiem, nastąpiła kulminacja dziejów, nastała pełnia czasu. Ku Niemu biegnie przeszłość i ku Niemu odnosi się przyszłość. Od Niego wychodzi i ku Niemu orientuje się cała historia, w Nim ma swój cel i sens oraz wypełnienie ${ }^{32}$.

W encyklice Centesimus annus, zwłaszcza w punktach 22-29, mamy niewątpliwie do czynienia z interpretacją „znaków czasu”. Teologia ujmuje znaki czasu jako widzialne wydarzenia w historii ludzkości, w życiu jednostkowym i społecznym. Pozostają one w ścisłym związku asocjacyjnym ze zbawczą inicjatywą Boga w stosunku do człowieka, która rozwija się w czasie, z działaniem Ducha Świętego w historii ludzkiej, tak iż pozwala to na odczytanie tego, czego Bóg od nas w danym momencie, w określonych okolicznościach oczekuje ${ }^{33}$. W soborowej Konstytucji duszpasterskiej o Kościele w świecie współczesnym jest wyraźny nakaz badania znaków czasu. Teologiczną refleksję nad znakami czasu prowadzi między innymi teologia pastoralna, a zwłaszcza jeden $\mathrm{z}$ najnowszych jej działów - kairologia. Badanie znaków czasu należy do pastoralnej strategii Kościoła ${ }^{34}$. Ich analiza nie sprowadza się jedynie do zwykłej diagnozy warunków zewnętrznych, w jakich Kościół prowadzi swą działalność zbawczą. Ma ona wyraźnie charakter pastoralny. Kościół powinien w sposób dostosowany do mentalności współczesnego człowieka odpowiedzieć na odwieczne pytania dotyczące jego egzystencji. Znaki czasów są ponaglającym wezwaniem do odkrywania nowych sposobów pastoralnego działania, podejmowanych w duchu Ewangelii ${ }^{35}$.

Samo wyrażenie „znaki czasu” nie było zbyt często przywoływane przez Jana Pawła II. Jednak idea znaków czasu jest mocno obecna w papieskim nauczaniu i zajmuje szczególne miejsce w Jego myśli teologicznej. Pojęcie to stosował Ojciec święty w znaczeniu wypracowanym przez

${ }^{31}$ Jan Paweł II, Przekroczyć próg nadziei. Jan Paweł II odpowiada na pytania Vittoria Messoriego, Lublin 1994, s. 61.

${ }^{32}$ K. Ryczan, Chrystolog dziejów, s. 31.

33 J. Majka, Metodologia nauk teologicznych, Wrocław 1981, s. 24.

${ }^{34}$ W. Przygoda, Paradygmaty postępowania badawczego w teologii praktycznej, s. 101.

${ }^{35}$ S. Bielecki, Teologia znaków czasu, Kielce 2006, s. 169. 
posoborową teologię. Przyjmował trzy wzajemnie ze sobą powiązane sposoby teologicznej interpretacji zachodzących w świecie wydarzeń, pozwalające dostrzec w nich znaki czasu. Chodzi mianowicie o odniesienie danego wydarzenia do wiary w stworzenie świata i człowieka przez Boga, do tajemnicy wcielenia Syna Bożego i dokonanego przezeń odkupienia, do sytuacji eschatologicznej, gdyż do niej dzięki mocy Ducha Świętego prowadzi cała historia zbawienia i historia ludzkości ${ }^{36}$.

Według teologów - komentatorów nauczania Jana Pawła II, klucz interpretacyjny do zrozumienia tej nauki podany został w encyklice Redemptor hominis. To tam Ojciec święty naszkicował trynitarny horyzont swego nauczania. Trynitarny, gdyż w jego enuncjacjach, chociaż w różny sposób, powraca ta sama odwieczna idea - Jezus Chrystus, który objawia Ojca, sam jest Jego objawieniem i wciąż to czyni przez obecność Ducha Świętego w życiu Kościoła. Właśnie z tej trynitarnej struktury możliwe było wyprowadzenie fundamentalnych zasad, leżących u podstaw encyklik społecznych, które pozornie tylko wydają się oddalone od tematyki teologicznej ${ }^{37}$. Zasadniczy zatem klucz do wyjaśnienia znajduje się w chrześcijańskiej antropologii, dlatego też przy lekturze rozdziału III Centesimus annus trzeba mieć na uwadze treść rozdziału vi, gdzie znajduje się wykład na temat chrześcijańskiej wizji człowieka. Antropologiczny argument pojawia się już w samej analizie przyczyn upadku systemów totalitarnych. W centrum zainteresowania papieża jest troska o człowieka i jego zbawienie. Nauka społeczna Kościoła „ma sama w sobie wartość narzędzia ewangelizacji: jako taka głosi ona Boga i tajemnicę zbawienia w Chrystusie każdemu człowiekowi i z tej samej racji objawia człowieka samemu sobie. W tym świetle - i wyłącznie w tym - podejmuje inne zagadnienia [...]"38. Ośrodkiem całego dziedzictwa doktrynalnego Kościoła jest człowiek w swej konkretnej rzeczywistości grzesznika i sprawiedliwego ${ }^{39}$. W nauczaniu i działaniach Ojca świętego Jana Pawła II widać otwarcie na problemy współczesnego świata oraz zaangażowanie $\mathrm{w}$ ich rozwiązywanie. Jednak punktem centralnym jego troski jest osoba

${ }^{36}$ J. Mazur, Znaki czasu, w: Encyklopedia nauczania społecznego Jana Pawła II, red. A. Zwoliński, Radom 2003, s. 604.

${ }^{37}$ R. Fisichella, Trynitarne znamię encyklik Jana Pawła II, w: Jan Paweł II Teolog. Komentarze do encyklik, s. 31-35.

${ }^{38}$ CA 54.

${ }^{39}$ CA 53. 
ludzka, z jej godnością odnajdywaną w tajemnicy wcielenia. Już w swojej pierwszej, programowej encyklice Redemptor hominis przypominał, że Kościół ma prawdę o człowieku głosić i jej bronić. „Kościół, który jest ożywiony wiarą eschatologiczną, uważa równocześnie tę troskę o człowieka, o jego człowieczeństwo, o przyszłość ludzi na tej ziemi, a więc o kierunek całego rozwoju i postępu - za istotny dla swego posłannictwa, za nierozerwalnie z nim związany. Początek tej troski Kościół znajduje w samym Jezusie Chrystusie - jak o tym świadczą Ewangelie - w Nim też stale pragnie ją rozwijać, odczytując sytuację człowieka w świecie współczesnym wedle najważniejszych znaków naszego czasu"40.

Pastoralne spojrzenie encykliki Centesimus annus na wydarzenia roku 1989 ujawnia się z pełną ostrością dopiero w kontekście całości nauczania papieskiego, a zwłaszcza w Jego teologii odczytywania znaków czasu. Wiodące wskazania metodologiczne w tej kwestii daje adhortacja $\mathrm{Pa}$ stores dabo vobis, gdzie Ojciec święty proponuje sposób diagnozy zwany

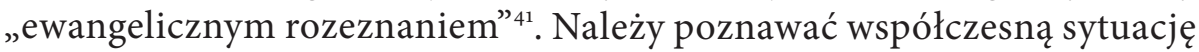
przez badania naukowe, a uzyskane wyniki połączyć z oceną moralną. Chrześcijańska interpretacja domaga się odczytywania tych sytuacji jako zadań życiowych (aspekt moralny) oraz odkrycia w nich wymiaru Bożego wezwania (aspekt religijny) ${ }^{42}$. W Centesimus annus Jan Paweł II stwierdził, że Kościół wypowiada się na temat określonych sytuacji ludzkich, formułując w ten sposób swoje nauczanie, „prawdziwy corpus doktrynalny, który pozwala mu analizować zjawiska społeczne, wypowiadać się na ich temat i wskazywać kierunki właściwego rozwiązywania problemów, które z nich wynikają" ${ }^{43}$. Jest to nowość w stosunku do czasów Leona XIII,

\footnotetext{
${ }^{40} \mathrm{RH} 15$.

${ }^{41}$ „Człowiek wierzący - pisze Jan Paweł II - interpretuje sytuację historyczną stosując zasadę poznania oraz kryterium konkretnych wyborów, które odnajduje w metodzie nowej i oryginalnej, czyli w ewangelicznym rozeznaniu. Interpretacja ta dokonuje się w świetle i w mocy Ewangelii, żywej i osobowej, którą jest Jezus Chrystus poprzez dar Ducha Świętego. $\mathrm{W}$ ten sposób ewangeliczne rozeznanie wydobywa $\mathrm{z}$ sytuacji historycznej oraz wydarzeń i okoliczności z nią związanych nie zwyczajne «dane», które należy zarejestrować dokładnie, pozostając wobec nich biernym i obojętnym, ale «zadanie», a wręcz wyzwanie skierowane do odpowiedzialności i wolności zarówno poszczególnej osoby, jak i wspólnoty. Jest to «wyzwanie», które łączy się z Bożym «wezwaniem», rozbrzmiewającym w tej samej sytuacji historycznej" (tenże, Posynodalna adhortacja apostolska Pastorem dabo vobis, 10).

${ }^{42}$ P. Bortkiewicz, Nauczyciel myślenia. Wokół myśli Jana Pawła II, s. 16.

${ }^{43}$ CA 5 .
} 
gdy istniało wyraźne rozdzielenie tendencji ukierunkowanych na ten świat, gdzie wiara była czymś obcym od koncepcji zbawienia wyłącznie pozaziemskiego, które jednak nie kształtowało aktywności człowieka na ziemi. Leonowa encyklika była znaczącym krokiem w potwierdzaniu prawa obecności Kościoła w zmiennej rzeczywistości społecznej. Jan Paweł II włącza nauczanie i upowszechnianie nauki społecznej w zakres ewangelizacyjnej misji Kościoła, jako istotną część orędzia chrześcijańskiego. Także nowa ewangelizacja musi uwzględnić koniecznie głoszenie nauki społecznej Kościoła ${ }^{44}$.

Interesującą intuicję w teologicznym interpretowaniu wydarzeń roku 1989 podpowiedział bp Alfons Nossol, powołując się na analizy Josepha Ratzingera dotyczące zmian w Europie oraz relacji Kościoła i świata. Oparta jest ona zasadach odczytywania znaków czasu. Ratzinger rozważał analogię pomiędzy upadkiem muru berlińskiego a zburzeniem murów Jerycha, zaznaczając, że nie wolno w nieuprawniony sposób przeprowadzać paraleli pomiędzy biblijną historią a wydarzeniami współczesnymi, aby nie dawać im pozoru fałszywej sakralności. Jednak wiara w Boga, a przynajmniej pytanie o Niego miały tutaj kluczowe znaczenie ${ }^{45}$. Według Ratzingera nowością rewolucyjnych przemian było to, że dokonały się one siłą ducha, a nie siłą polityczną czy militarną. Dlatego też proces zmian wykracza poza wymiar lokalny i polityczny, ponieważ wyrasta z rzeczywistości metapolitycznej, aby potem ujawnić polityczną siłę tych niepolitycznych czynników ${ }^{46}$. Po lekturze rozdziału „Rok 1989” w encyklice Centesimus annus nie ma wątpliwości, że taki sposób interpretacji

${ }^{44}$ Por. tamże.

${ }^{45}$ Joseph Ratzinger pisze na ten temat: „Nie ma już ideologicznego muru, który dzielił nie tylko Europę, ale w niewidzialny sposób na każdym miejscu również cały świat. I nie został on powalony siłą oręża, zapewne też nie wprost przez modlitwę, ale przez eksplozję ducha, przez procesję na rzecz wolności, co w końcu okazało się silniejsze od kolczastego drutu i betonu. Duch udowodnił swoją moc; dźwięk trąb wolności był mocniejszy niż mur, który miał wyznaczać granice. I jeżeli nie potrafimy bezpośrednio umieścić Boga w tej rozgrywce, to jednak na zawsze pozostanie prawdą to, że wiara w Niego, a przynajmniej pytanie o Niego miały niebagatelne znaczenie w zaintonowaniu owego wyzwalającego dźwięku trąb" (J. Ratzinger, Wendezeit für Europa? Diagnosen und Prognosen zur Lage von Kirche und Welt, Freiburg 1991, cyt. za: A. Nossol, Przemiany 1989 roku jako nowe wyzwanie dla Kościoła w Europie środkowo-wschodniej, w: Jan Paweł II, „Centesimus annus”. Tekst i komentarze, Lublin 1998, s. 92-93).

${ }^{46}$ A. Nossol, Przemiany 1989 roku jako nowe wyzwanie dla Kościoła..., s. 90-91. 
przyświecał Janowi Pawłowi II. Ojciec święty, nawiązując do trudnego czasu przełomu, zaznaczył, że dokonał się on w sposób pokojowy i ma uniwersalne znaczenie, a jego następstwa „stanowią raczej okazje, w których ludzka wolność może współpracować z miłosiernym planem Boga działającego w historii” ${ }^{47}$. Przyznał też, że nie przestaje „dziękować Bogu, że wsparł ludzkie serca w czasie tej trudnej próby" ${ }^{38}$. O walce, która doprowadziła do przemian, a wymagała umiarkowania, ofiar i cierpień, papież napisał: „W pewnym sensie zrodziła się ona z modlitwy i z pewnością byłaby nie do pomyślenia bez nieograniczonego zaufania Bogu, który jest Panem historii i kształtuje serce człowieka. Łącząc własne cierpienia za prawdę i za wolność z cierpieniem Chrystusa na Krzyżu, człowiek może dokonać cudu pokoju [...]"49. Przypomniał też, że chrześcijanin w doczesności musi walczyć ze złem. „Dopiero na końcu dziejów Pan powróci w chwale na sąd ostateczny i ustanowi nowe niebiosa i nową ziemię" ${ }^{50}$. Do typowo pastoralnych akcentów należy zaliczyć także wątki poświęcone roli Kościoła w przemianach społeczno-politycznych, jego zadaniach na przyszłość, misji na polu społecznym.

Zadaniem powyższych analiz było pokazanie "pastoralnego wglądu” encykliki Centesimus annus w wydarzenia 1989 roku. Temat taki bardzo rzadko był podnoszony w komentarzach i wypowiedziach na temat encykliki, które skupiały się bardziej na kwestiach ekonomicznych, politycznych, socjologicznych, kulturowych aniżeli teologicznych. Pastoralny aspekt w spojrzeniu Jana Pawła II na rewolucyjne zmiany roku 1989 implikuje ich traktowanie jako znaków czasu. Z perspektywy 25 lat można powiedzieć, że nie były to pojedyncze wydarzenia, ale zjawiska, które mają długotrwałe konsekwencje w życiu indywidualnym i zbiorowym. Encyklika w ich interpretacji wielokrotnie odwołuje się do planu Boga działającego w historii. Pastoralny charakter interpretacji wydarzeń roku 1989 ujawnia się także w tym, iż pierwszym przedmiotem troski jest każdy konkretny człowiek, wpleciony w liczne sytuacje teraźniejszości. Zdolność rozumienia człowieka Kościół czerpie z objawienia. Jako pastoralny element przesłania encykliki można uznać te wszystkie wątki,

\footnotetext{
47 CA 26.

${ }^{48}$ CA 23.

49 CA 25.

50 Tamże.
} 
które dotyczą Kościoła, jego misji i działania w świecie. Chodzi tu także o rolę, jaką odegrał on w przemianach społecznych 1989 roku.

\section{Bibliografia}

Bielecki S., Teologia znaków czasu, Kielce 2006.

Bortkiewicz P., Nauczyciel myślenia. Wokół myśli Jana Pawła II, Gdańsk 2005.

Fisichella R., Trynitarne znamię encyklik Jana Pawła II, w: Jan Paweł II Teolog. Komentarze do encyklik, red. G. Borgonovo, A. Cattaneo, wstęp do wyd. pol. K. Nycz, tłum. E. Augustyn, R. Cielicki, Warszawa 2009, s. 31-41.

Fontana S., Corpus doktrynalny. Nauka społeczna jako organiczna całość, „Społeczeństwo" 9 (1999), nr 1, s. 63-80.

Jan Paweł II, Encyklika Centesimus annus, przedruk: Libreria Editrice Vaticana, Włocławek 1991.

Jan Paweł II, Encyklika Redemptor hominis, Poznań 1979.

Jan Paweł II, Encyklika Sollicitudo rei socialis, Warszawa 1988.

Jan Paweł II, Posynodalna adhortacja apostolska Pastores dabo vobis, Watykan 1992.

Jan Paweł II, Przekroczyć próg nadziei. Jan Paweł II odpowiada na pytania Vittoria Messoriego, Lublin 1994.

Jan XXIII, Encyklika Mater et magistra, Société d'Éditions Internationales, Paris 1963.

Kamiński R., Tożsamość metodologiczna teologii pastoralnej, w: Metodologia teologii praktycznej, red. W. Przyczyna, Kraków 2011, s. 37-55.

Kongregacja ds. Wychowania Katolickiego, Wskazania dotyczące studiów i nauczania doktryny społecznej Kościoła $w$ ramach formacji kapłańskiej, 30.12.1988, „L'Osservatore Romano”, wyd. pol., 10 (1989).

Majka J., Metodologia nauk teologicznych, Wrocław 1981.

Mazur J., Znaki czasu, w: Encyklopedia nauczania społecznego Jana Pawła II, red. A. Zwoliński, Radom 2003, s. 603-606.

Michałowski J., „Centesimus annus” - jaki kapitalizm, w: Jan Paweł II, „Centesimus annus". Tekst i komentarze, red. F. Kampka, C. Ritter, Lublin 1998, s. 227-245.

Nossol A., Przemiany 1989 roku jako nowe wyzwanie dla Kościoła w Europie Srodkowo-Wschodniej, w: Jan Paweł II, „Centesimus annus”. Tekst i komentarze, red. F. Kampka, C. Ritter, Lublin 1998, s. 89-98.

Oschovsky B., Rok 1989 - europejski czas pamięci, http://www.enrs.eu/pl/articles/130-rok-1989-europejski-czas-pamieci (14.01.2016). 
Przygoda W., Paradygmaty postępowania badawczego $w$ teologii praktycznej, w: Metodologia teologii praktycznej, red. W. Przyczyna, Kraków 2011, S. 97-114.

Ratzinger J., Wendezeit für Europa? Diagnosen und Prognosen zur Lage von Kirche und Welt, Freiburg 1991.

Restrepo S. B., Odczytując "Centesimus annus” w nowym tysiącleciu, „Społeczeństwo" 43-44 (2001), nr 3-4, s. 389-403.

Rhonheimer M., Polityczny i ekonomiczny realizm wspótczesnego świata oraz jego założenia etyczne i kulturowe. Encyklika „Centesimus annus” - 1 maja 1991 roku, w: Jan Paweł II Teolog. Komentarze do encyklik, red. G. Borgonovo, A. Cattaneo, wstęp do wyd. pol. K. Nycz, tłum. E. Augustyn, R. Cielicki, Warszawa 2009, s. 151-172.

Ryczan K., Chrystolog dziejów, w: Świadka świadkowie, red. M. Rusecki, S. Wilk, Lublin 2008, s. 21-35.

Weigel G., „Centesimus annus” a przyszłość demokracji: powtórna lektura, w: Jan Paweł II, „Centesimus annus”. Tekst i komentarze, red. F. Kampka, C. Ritter, Lublin 1998, s. 115-131.

Żeleźnik T., Encyklika „Centesimus annus” i przemiany w Polsce, „Społeczeństwo” 43-44 (2001), nr 3-4, s. 405-422.

\section{Abstrakt}

Z perspektywy 25 lat od wydania encykliki Centesimus annus z jeszcze większą wyrazistością rysuje się jej pastoralno-teologiczna refleksja nad wydarzeniami roku 1989. W wydarzeniach tych, których kulminacyjnym punktem był upadek komunizmu, Jan Paweł II dostrzega znaki czasu. Jako metodę ich diagnozy proponuje ewangeliczne rozeznanie. Encyklika daje jasny obraz społecznych, ekonomicznych i politycznych przyczyn rewolucji 1989 roku oraz ich konsekwencji. W centrum papieskiej diagnozy pozostaje jednak nie świat, ale osoba ludzka, której wielkość i godność odnajdują się ostatecznie w tajemnicy wcielenia i odkupienia. Jan Paweł II łączy historię konkretnego człowieka $\mathrm{z}$ historią zbawienia. W sytuacjach teraźniejszości chrześcijanin winien odczytać głos Bożego wezwania. 
Centesimus annus - pastoral insight into 1989

\begin{abstract}
From the perspective of 25 years of the encyclical letter Centesimus annus with even greater clarity draws its pastoral-theological reflection on the events of 1989. In these events, culminated in fall of communism, John Paul II sees signs of the times. He proposes evangelical understanding as a method of diagnosis of these events. The encyclical letter gives a clear picture of the social, economic and political causes of the 1989 revolution and its consequences. In the center of the Pope's diagnosis remains not the world, but the human person, the greatness and dignity are ultimately in the mystery of the incarnation and redemption. John Paul II connects story of every single human being with the history of salvation. In the present day situation Christians should read the voice of God's calling.
\end{abstract}

